\title{
THE
}
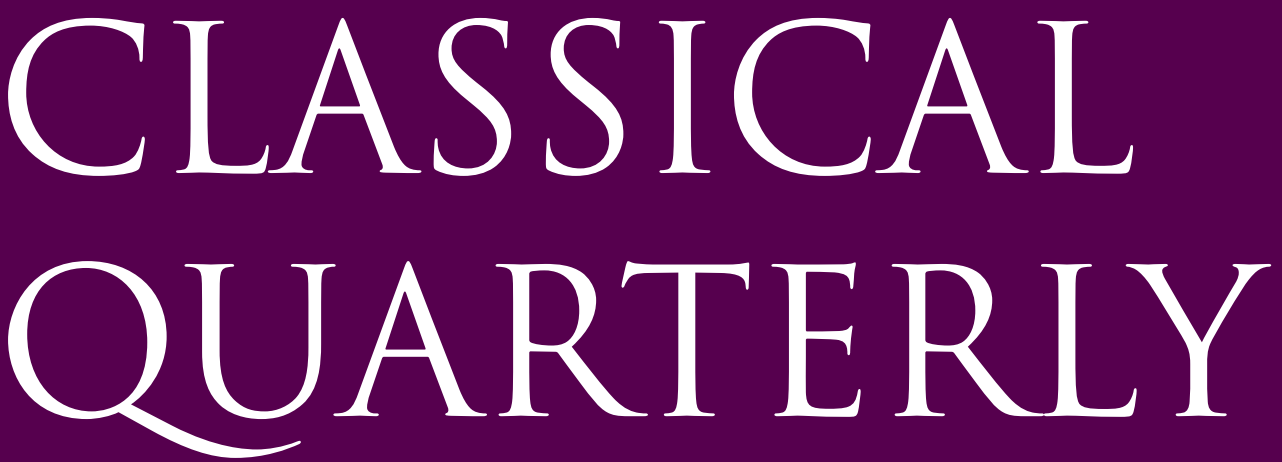

NEW SERIES

VOLUME 67 • NUMBER 2 • 2017

PUBLISHED FOR THE CLASSICAL ASSOCIATION BY CAMBRIDGE UNIVERSITY PRESS 


\section{CLASSICAL QUARTERLY}

PUBLISHED IN MAY AND DECEMBER IN EACH YEAR

\section{CLASSICAL ASSOCIATION JOURNALS BOARD}

Professor D. Cairns (Chairman)

Miss C. Davenport (Secretary)

Dr F. Budelmann

Professor R.K. Gibson

Mr P. Hooker

Dr R. Langlands

Dr F. Santangelo

Dr E.J. Stafford

Professor C. Steel

\author{
Ex officio \\ Professor B.J. Gibson (Editor, Classical Quarterly) \\ Dr A. Morrison (Editor, Classical Quarterly) \\ Professor C. Panayotakis (Editor, Classical \\ Quarterly) \\ Professor G. Manuwald (Editor, Classical Review) \\ Dr R. Rees (Editor, Classical Review) \\ Dr I. Petrovic (Editor, Greece \& Rome) \\ Dr A. Petrovic (Editor, Greece \& Rome) \\ Dr P. Horky (Editor, New Surveys in the Classics) \\ Dr J. Taylor (Editor, New Surveys in the Classics) \\ Mr S. Hunt (Editor, The Fournal of Classics Teaching)
}

\author{
ADMINISTRATOR \\ Clare Roberts, Classical Association, UK
}

\section{EDITORS}

Bruce Gibson, University of Liverpool, UK Andrew Morrison, Manchester University, UK Costas Panayotakis, University of Glasgow, UK

The Classical Quarterly is published by Cambridge University Press on behalf of the Classical Association. It is under the control of a Journals Board consisting of a Chair appointed by the Council of the Classical Association, the Chair of the Council, the Secretary to the Council, the Treasurer, and six further members appointed by Council.

\section{CONTRIBUTIONS TO THE JOURNAL}

Contributions and correspondence on its subject matter should be addressed by email to the CQ Administrator, Clare Roberts (address: classicalquarterly@classicalassociation.org). Authors are requested to consult and follow the 'Notes to Contributors' found online at: www.classicalassociation.org/Journals/CQNotesforContributors.pdf

\section{SUBSCRIPTIONS}

The Classical Quarterly (ISSN 0009-8388) is published twice a year in May and December. Two parts form a volume. The subscription price which includes delivery by air where appropriate (but excluding VAT) of volume 67,2017 , which includes print and online access, is $£ 197.00$ (US $\$ 354.00$ in USA, Canada and Mexico) for institutions. The online-only price available to institutions is $£ 174.00$ (US \$314.00). Members of the Classical Association may subscribe at reduced rates. Single parts are $£ 113.00$ (US $\$ 204.00$ in USA, Canada and Mexico) plus postage. EU subscribers (outside the UK) who are not registered for VAT should add VAT at their country's rate. VAT registered members should provide their VAT registration number. Japanese prices for institutions (including ASP delivery) are available from Kinokuniya Company Ltd, P.O. Box 55, Chitose, Tokyo 156, Japan.

Orders, which must be accompanied by payment, may be sent to your subscription agent or direct to the publisher: Cambridge University Press, Journals Fulfilment Department, UPH, Shaftesbury Road, Cambridge CB2 8BS; or in the USA, Canada and Mexico: Cambridge University Press, 1 Liberty Plaza, Floor 20, New York, NY 10006, USA. Periodicals postage paid at New York, NY and at additional mailing offices.

\section{COPYING}

This journal is registered with the Copyright Clearance Center, 222 Rosewood Drive, Danvers, MA 01923, USA. Organisations in the USA who are also registered with the C.C.C. may therefore copy material (beyond the limits permitted by sections 107 and 108 of U.S. Copyright law) subject to payment to the C.C.C. of the per copy fee of $\$ 30.00$. This consent does not extend to multiple copying for promotional or commercial purposes. Code 0009-8388/16. ISI Tear Sheet Service, 3501 Market Street, Philadelphia, PA 19104, USA, is authorised to supply single copies of separate articles for private use only. Organisations authorised by the Copyright Licensing Agency may also copy material, subject to the usual conditions. For all other use, permission should be sought from Cambridge or from the American Branch of Cambridge University Press.

The Classical Quarterly is included in the Cambridge Journals Online journals service, which can be found at http://journals.cambridge.org/jid_CAQ. Tables of contents are freely available. The full text is available online from your desktop if your library has a subscription, or if you subscribe as a member of the Classical Association. For further information on other Press journals access http://cambridge.org/journals.

(C) The Classical Association 2017

ISSN 0009-8388

Printed in the United Kingdom by Bell and Bain, Glasgow, UK 


\section{CLASSICAL QUARTERLY}

NEW SERIES DECEMBER 2017 VOL. 67 NO. 2

\section{CONTENTS}

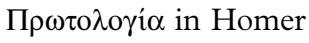

F.S. Naiden

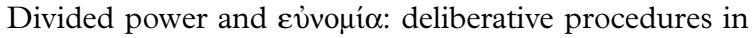
ancient Sparta

Alberto Esu

353

Anaximander's Spartan sundial

Philip Thibodeau

374

Protagoras' Great Speech

A.R. Nathan

380

Decrees in Andocides' On the Mysteries and 'latent fragments' from Craterus

Edwin Carawan

400

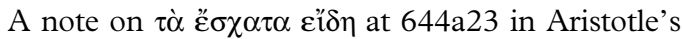

Part. an. 1.4

Errol G. Katayama

422

Private participation in ruler cults: dedications to

Philip Sōtēr and other Hellenistic kings Theodora Suk Fong Fim

Associations and institutions in Athenian citizenship procedures

Greek local historiography and its audiences

Fames Kierstead

The imperative in -to in Plautus and Terence

Daniel Tober

460

'Nonsense' in comic scholia

Peter Barrios-Lech

485

Narrative focalization and the historical present in

Catullus 64

Stephen E. Kidd

Memmius the Epicurean

Boris Kayachev

522

Furrowing prows: Varro of Atax's Argonautae and transgressive sailing in Virgil's Aeneid

Christopher B. Polt

A Petronian parrot in a Neronian cage: a new reading of Statius' Silvae 2.4

Leah Kronenberg

Unseen and unharmed: a case study in understanding opisthographic epitaphs

Inger N.I. Kuin

Fabius and Minucius in Tacitus: intertextuality and allusion in Annals Book 15

Timekeeping in the Roman army

Arthur F. Pomeroy

George Cupcea

Plato's pilot in the political strategy of Julian and Libanius

David Neal Greenwood

The Roman kings in Orosius' Historiae aduersum paganos

Mattias Gassman

Latent criticism of Anthemius and Ricimer in Sidonius Apollinaris' Epistulae 1.5

Michael Hanaghan 


\section{Shorter Notes}

Aristophanes' Acharnians 591-2: a proposed new interpretation

'Hippias, handsome and wise': a note on a bon mot in Plato, Hp. mai. 281a1

Fructus amoris: on Catullus 55.17-22

Wilfried H. Lingenberg

656

Pindar as laudator equorum in Horace, Carmina 4.2.17-20 and Ars Poetica 83-5

David Kovacs

659

Fire and its Asian worshippers: a note on Firmicus

Maternus' De errore profanarum religionum 5.1 